\title{
Transvaginal ultrasound-guided reduction of twin conceptuses in the mare
}

\author{
Lee H.A. Morris', R.E.S. Greenwood² and W.R. Allen ${ }^{1}$ \\ 1 University of Cambridge, Department of Clinical Veterinary Medicine, Equine Fertility Unit, Mertoun Paddocks, Cambridge \\ 2 Reynolds House, High Street, Newmarket, Suffolk
}

\begin{abstract}
Summary
It is now possible to treat mares carrying twin conceptuses between days 35 and 55 of gestation by transvaginal ultrasound-guided aspiration of the allantoic fluid of one of the conceptuses. In this review of six mares treated in this manner, two successfully carried a singleton to term, one mare continued to carry live twins to term, another subsequently lost the remaining singleton conceptus after 100 days of gestation and two lost both conceptuses within 3 days of the aspiration procedure. These results reveal the potential value of the technique but highlights the need for further research to determine the optimum stage of gestation at which to carry it out in order to maximize the chances of survival of the remaining fetus.
\end{abstract}

Keywords: $\quad$ twin, transvaginal ultrasound, mare, allantois, aspiration

\section{Transvaginale, ultrasonographiegeführte Reduktion von Zwillingsanlagen bei der Stute}

Es ist möglich geworden, Zwillingsanlagen bei der Stute zwischen Trächtigkeitstag 35 und 55 mittels transvaginaler, ultrasonographiegestützter selektiver Aspiration von Allantoisflüssigkeit auf einen Einling zu reduzieren. In der vorliegenden Übersicht von sechs Stuten, die in dieser Weise behandelt wurden, trugen zwei Stuten einen Einling bis zum normalen Geburtstermin aus, eine Stute trug weiterhin Zwillinge aus, eine weitere Stute verlor einen Einling nach ca 100 Tagen Gravidiät. Zwei Stuten verloren beide Fruchtanlagen innerhalb von 3 Tagen nach der Aspiration. Die Untersuchungsergebnisse belegen grundsätzlich die Brauchbarkeit der Methode, sie zeigen aber auch deutlich auf, dass weiterer Forschungsbedarf auf diesem Gebiet besteht. Insbesondere dürtte die Terminierung des Trächtigkeitszeitpunktes zu definieren sein, der optimal für die Aspiration ist und die Überlebenschancen des verbliebenen Einlings wesentlich erhöht.

Schlüsselwörter: Zwillinge, transvaginale Ultraschalluntersuchung, Stute, Allantois, Aspiration

\section{Introduction}

Since the advent of transrectal ultrasound scanning for early accurate diagnosis of pregnancy in the mare in the early 1980's (Palmer and Driancourt, 1980; Simpson et al., 1982) the overall twin conception rate in Thoroughbred mares in the United Kingdom has risen from 2.2\% in 1983 (Sanderson and Allen, 1987) to around $7.2 \%$ in 1998 (authors, unpublished data). This increase is almost certainly due to a combination of the increased accuracy of diagnosis of twins using modern high resolution scanners with 5.0 and $7.5 \mathrm{MHz}$ transducers and the high rate of success (>95\%) when manually crushing one conceptus per rectum before day 20 of gestation; increased survival of female embryos to term will inevitably hasten the spread of twinning genes within the population.

Of 95 twin conceptions diagnosed between days 13 and 22 of gestation in Thoroughbred mares in the Newmarket region of England during the 1998 breeding season, 8 were not treated. The twin conceptuses in 4 of these mares had reduced spontaneously to a singleton, and both conceptuses had disappeared in the other 4 mares, by the time of their subsequent pregnancy examinations (authors, unpublished data). Pascoe (1983) noted that only some 13\% of mares left carrying untreated twin conceptuses gave birth to a single live foal and those that aborted twins suffered an increased risk of dystocia and reduced fertility in the follo- wing breeding season. Furthermore, twin foals that do survive to term are usually undersized and they show increased perinatal mortality (Jeffcott and Whitwell, 1973; Merkt et al., 1982; Pascoe, 1983). The study by Jeffcott and Whitwell (1973) indicated that $22 \%$ of the spontaneous abortions in Thoroughbred mares in the U.K. during the period between 1967 and 1970 were caused by twinning whereas nowadays, with early ultrasound scanning and successful crushing of one conceptus, the equivalent figure has fallen to $7 \%$ (A. Blunden, personal communication). Nonetheless, undiagnosed twin pregnancies still represent an economic loss in time and fertility within the Thoroughbred breeding industry, especially in those mares in which persistence of the eCG-secreting fetal endometrial cups in the maternal endometrium after removal of the twins suppresses oestrus and ovulation for many months (Allen et al., 1973).

Treatment options for managing undiagnosed twins beyond day 35 of gestation have included serial daily injections of prostaglandin $F_{2}$ analogues to cause lutoelysis and abortion (Daels et al. 1989), attempted manual crushing of one conceptus (Roberts, 1982), surgical removal of one conceptus (Pascoe and Stover, 1989), blind transvaginal aspiration of allantoic fluid from one conceptus (Pascoe, 1979), dietary restriction of the mare (Merkt et al., 1982) or 
transabdominal ultrasound-guided injection of concentrated $\mathrm{KCl}$ into the heart (Rantanen and Kincaid, 1988) or intrathoracic injection of procaine penicillin (McKinnon and Rantanen, 1998), after day 100 of gestation. A transvaginal ultrasound-guided technique for aspirating fetal fluids from singleton or twin conceptuses between days 20 and 65 of gestation has been described by Bracher et al. (1993), Macpherson et al. (1995) and Squires et al. (1994) and this paper discusses the use of this transvaginal approach to treat 6 cases of twins between days 35 and 55 .

\section{Materials and methods}

The procedure was carried out on 6 mares carrying twins, one at day 35 , two at day 45 , one at day 48 , one at day 50 and one at day 55, of gestation. In addition, 6 experimental mares carrying singleton conceptuses underwent transvaginal ultrasound-guided aspiration of allantoic fluid on day 32 of gestation followed immediately by videoendoscopic examination of the punctured conceptus in the uterus as described by Bracher and Allen (1992).

With the mare restrained in stocks, the sizes and location of the twin conceptuses within the uterus was determined by transrectal linear array ultrasonography and the choice made as to which would be easiest to grasp and penetrate with the needle. Around $20 \mathrm{ml}$ of local anaesthetic (2\% Lignocaine Hydrochloride; C-Vet Veterinary Products, Leyland, UK) was infused into the mare's rectum to achieve relaxation for improved manipulation of the uterus. A nose twitch was applied to the mare for additional restraint if and when necessary but pharmacological sedation was avoided in order to maintain good uterine tone. The $6.5 \mathrm{MHz}$ curvilinear ultrasound probe (Dynamic Imaging Ltd, Lothian, UK) was enveloped in a plastic rectal glove with the fingers removed, lubricated with sterile gel ( $\mathrm{K}-\mathrm{Y}$ jelly; Johnson and Johnson Ltd, Maidenhead, UK) and guided into the vagina using a sterile gloved hand. The operator's hand was then withdrawn from the vagina and inserted into the rectum in order to pull the gravid horn backwards into the pelvic cavity and hold it there. Once the uterus was fixed in a suitable position, the ultrasound probe was advanced to make contact with the cranial wall of the vagina and the conceptus selected for elimination was identified on the ultrasound monitor. A $60 \mathrm{~cm}, 16$ gauge, single lumen needle (Cook Veterinary Products, Brisbane, Australia) was inserted into the needle guide attached to the ultrasound probe by a second operator. The needle was advanced in the guide until, with a sharp defined thrust, it pierced the vaginal and uterine walls and the conceptus membranes. The progress of the needle was visible on the ultrasound monitor and when it entered the allantoic cavity between 60 and $180 \mathrm{ml}$ of clear fluid was aspirated using a $60 \mathrm{ml}$ syringe. Subsequently, the needle was retracted and the probe withdrawn from the vagina.

In one mare, which underwent the procedure on day 48 of gestation, the orally active progestagen, altrenogest (Regumate; Hoechst Roussel Vet, Bucks, UK) and the prosta- glandin synthetase inhibitor, flunixin meglumine (Finadyne; Schering Plough, Middlesex, UK) were administered once daily from one day before, to three days after, the manipulation.

\section{Results}

The results of the transvaginal aspiration attempts are summarized in Table 1. Only two of the 6 treated mares (33\%) produced live singleton foals at term. One other mare, aspirated at day 35 of gestation, carried a singleton conceptus until at least day 100, but thereafter underwent an unobserved spontaneous abortion. Another mare, treated on day 45 of gestation, subsequently carried both conceptuses to term and the continuation of the twins was not recognised by the referring veterinary surgeon when carrying out 6 once-weekly post-treatment ultrasound examinations. Both foals were born live from a spontaneous parturition but the smaller of the two survived for only 48 hours. In the two mares, treated on days 45 and 48 days of gestation respectively, both conceptuses had died within 3 days after the aspiration procedure and the mares were given serial daily injections of the prostaglandin $F_{2 \alpha}$ analogue, cloprostenol (Estrumate, Schering-Plough, Middlesex, UK) to induce luteolysis and expulsion of the fetal remnants. There was no evidence of intrauterine infection associated with either of these failures.

Hysteroscopic examination of the 6 mares that underwent transvaginal aspiration of allantoic fluid from a singleton conceptus revealed a single entrance hole in either the chorioallantoic or choriovitelline membranes. The conceptus had collapsed and there was evidence of haemorrhage from chorionic blood vessels. However, there were no obvious accumulations of allantoic fluid within the uterine lumen.

The placenta was obtained from the 17 y.o. maiden mare carrying twins that underwent allantoic aspiration on day 55 of gestation and carried the remaining singleton foal to term. The placenta was passed intact within 10 minutes after birth of the foal, which was healthy and vigorous and

Tab. 1: Transvaginal ultrasound-guided aspiration of allantoic fluid from one of twin conceptuses in the mare

Transvaginale, ultraschallgeführte Aspiration der Allantoisflüssigkeit einer Frucht einer Zwillingsträchtigkeit

\begin{tabular}{|c|c|c|c|}
\hline $\begin{array}{c}\text { Mare } \\
\text { number }\end{array}$ & $\begin{array}{c}\text { Stage of gestation } \\
\text { at time of } \\
\text { aspiration } \\
\text { (days) }\end{array}$ & $\begin{array}{c}\text { Distribution of the } \\
\text { conceptuses within } \\
\text { the uterus }\end{array}$ & $\begin{array}{c}\text { Number of foals } \\
\text { born alive }\end{array}$ \\
\hline 1 & 35 & Unilateral & 0 \\
\hline 2 & 45 & Unilateral & 0 \\
\hline 3 & 45 & Bilateral & 1 \\
\hline 4 & 45 & Bilateral & 2 \\
\hline 5 & 48 & Bilateral & 0 \\
\hline 6 & 55 & Bilateral & 1 \\
\hline
\end{tabular}


had an estimated bodyweight of $40 \mathrm{~kg}$. The allantochorion weighed $3.02 \mathrm{~kg}$ and it exhibited a star shaped avillous area near the junction between the body and the gravid horn regions of the placenta, representing the area of apposition of the two placentas at the time of aspiration (Figure 1a). A mummified conceptus measuring $2.5 \times 1.5 \mathrm{~cm}$ was attached to this avillous region by a fibrous pedicle and directly opposite it a large pedunculated allantochorionic pouch protruded into the allantoic cavity (Figure 1b).

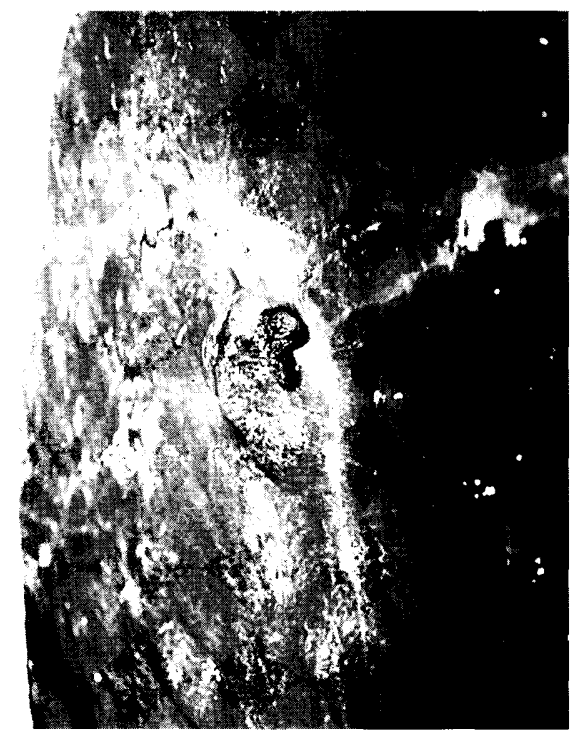

Fig. 1a: Mummified fetus attached to the chorion of the surviving twin

Am Chorion des überlebenden Zwillingspartners haftender mumifizierter Fetus

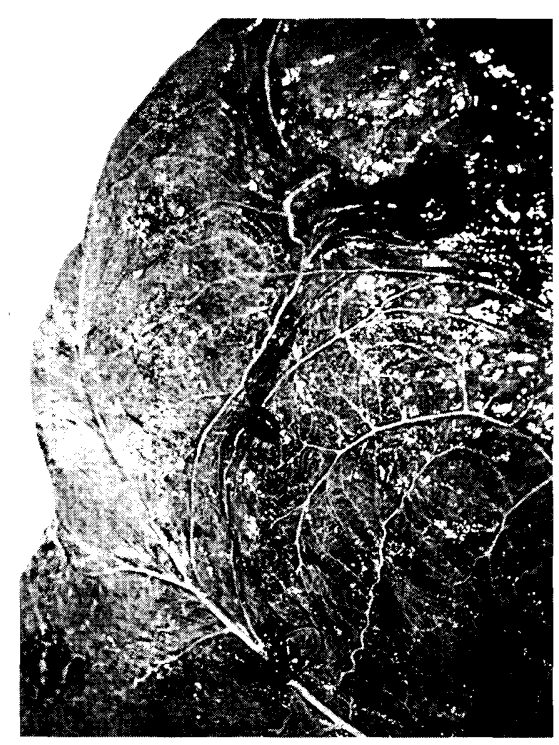

Fig. 1b: Allantochorionic pouch apposing the mummified fetus

Mumifizierter Fetus eingepasst in eine Allantochoriontasche

\section{Discussion}

Ideally, twin conceptuses are nowadays diagnosed and treated successfully within 13-17 days after ovulation and well before the formation of the gonadotrophin-secreting endometrial cups. However, for a variety of reasons this does not always occur and a few pairs of twins persist beyond the crucial stage of day 34-36 after ovulation when the progenitor chorionic girdle invades the maternal endometrium and the endometrial cup secretion is set in motion (Allen et al., 1973). The present use of transvaginal ultrasound-guided aspiration to eliminate one of the twin conceptuses after day 35 offers an alternative to aborting both conceptuses and trying, usually in vain, to induce the mare to return to oestrus so she can be mated again.

The technique is very dependent upon adherence to strict hygiene to avoid introducing bacteria into the progesterone-dominated, and hence very susceptible, uterus. The speed and ease of the manipulation may also influence the results. Technically, the uterus is easier to grasp and fix within the pelvis before it begins to extend beyond the pelvic brim around day 40 . However, the viability of the remaining conceptus may be improved if the aspiration is carried out at later stages of gestation (i.e. $>$ day 50 ) when the developing chorionic villi have achieved a more definite and stable interdigitation with the endometrial epithelium, but the gravid uterus is still not too pendulous to manipulate into the pelvis.

Success of the technique is obviously the production of a single viable foal at term. Examination of the placenta and foal from one of the survivors in this study showed both to be at the lower end of the normal range for an aged, maiden Thoroughbred mare (Sandra Wilsher and W.R. Allen, unpublished data). It is also clear that two extremes of failure are possible. In one case, the production of twins at term revealed the resilience of the conceptuses to manipulation and localized trauma, which can be assumed to have been induced by the technique based upon hysteroscopic observations made in this study. On the other hand, the risk of losing both conceptuses also remains quite high. In both cases in this study the two conceptuses failed within 2 days of the procedure, which is consistent with the results of the earlier studies on transvaginal ultrasound-guided allantoic aspiration of singleton pregnancies (Macpherson et al., 1995; Squires et al., 1994). Bracher et al. (1993) defined success as the presence of viable singleton at 10 days after the aspiration of the co-twin and they therefore failed to account for possible losses at later stages of gestation. However, in one such case in the present study it was not possible to determine if the abortion was due to the aspiration procedure undertaken some weeks previously or was from an unrelated cause.

The absence of significant accumulations of fluid in the uterine lumen two days after the procedure in our 6 clinical cases of twins and the 6 experimental cases of singletons, differs from the results of the previous studies performed on singleton conceptuses (Macpherson et al., 1995; Squires et al., 1994) and the study performed on twins (Bracher et al., 1993). The former authors administered progestagen to their aspirated mares and demonstrated lower concentrations of prostaglandin metabolites in the blood of the mares that retained a viable fetus compared to those in which the fetus died. Squires et al. (1994) noted that, despite an initial 
fall in serum progesterone concentrations 2-4 days after the procedure, the corpus luteum did not regress completely and progesterone levels rose again. It is most likely that the eCG secreted at this later stage of gestation helps to maintain and protect the corpora lutea from the potentially luteolytic actions of any prostaglandin released as a consequence of the aspiration procedure.

At this preliminary stage in the development and application of the technique, it is not possible to draw conclusions regarding any effects of the treatment on the birthsize and growth rate of the surviving foal. However, with further refinement of the method and investigation into the optimum stage of gestation at which to carry out aspiration of the allantois, the technique may hopefully become a reliable method of reducing twin conceptuses to a viable singleton in the mare.

\section{Literature}

Allen, W.R, Hamilton, D.W. and Moor, R.M. (1973): The origin of the equine endometrial cups: II. Invasion of the endometrium by trophoblast. Anat. Rec. 177, 503-518.

Bracher, V. and Allen, W.R. (1992): Videoendoscopic evaluation of the mare's uterus: I. Findings in normal fertile mares. Equine vet. J. 24 , 274-278.

Bracher, V., Parlevliet, J.M., Pieterse, M.C., Vos, P.L.A.M., Wiemer, P., Taverne, M.A.M. and Colenbrander, B. (1993): Transvaginal ultrasound-guided twin reduction in the mare. Vet. Rec. 133, 478-479.

Daels, P.F., Stabenfeldt, G.H., Kindahl, H. and Hughes, J.P. (1989): Prostaglandin release and luteolysis associated with physiological and pathological conditions of the reproductive cycle of the mare: a review. Equine vet J. Suppl 8, 29-34.

Jeffcott, L.B. and Whitwell, K.E. (1973): Twinning as a cause of foetal and neonatal loss in the Thoroughbred mare. J.Comp. Path. 83, 91-106.

Macpherson, M.L., Homco, L.D., Varner, D.D., Blanchard, T.L., Harms, P.G., Flanagan, M.N. and Forrest, D.F. (1995): Transvaginal ultrasound-guided centesis for pregnancy elimination in the mare. Biol. Reprod. Mono I, 215-223

McKinnon, A.O. and Rantanen, N.W. (1998): Twins In: Equine Diagnostic Ultrasonography Ed N.W. Rantanen and A.O. McKinnon, pp 141-156 Williams and Wilkins, Waverly Philadelphia

Merkt, H., Jungnickel, S. and Klug, E. (1982): Reduction of early twin pregnancy to a single pregnancy by dietic means. J. Reprod. Fert. Suppl. 32, 451-452.

Palmer, E. and Draincourt, M.A. (1980): Use of ultrasonic echography in equine gynecology. Theriogenology 13, 203-216.
Pascoe, R.R. (1979): A possible new treatment for twin pregnancy in the mare. Equine vet. J. 11, 64-65

Pascoe, R.R. (1983): Methods for the treatment of twin pregnancy in the mare. Equine vet. J. 15, 40-42

Pascoe, D.R. and Stover, S.M., (1989): Surgical removal of one conceptus from fifteen mares with twin conceptuses. Vet. Surg. 18, 141-145.

Roberts, C.J. (1982): Termination of twin gestation by blastocyst crush in the broodmare. J. Reprod. Fert. Suppl. 32, 447-449.

Sanderson, M. and Allen, W.R. (1987): Reproductive efficiency of Thoroughbred mares in the United Kingdom. In Proceedings of the Ninth Bain-Fallon Memorial Lectures Ed P. Huntington pp31-41 Aust. Eq. Vet. Assoc, Sydney

Simpson, D.J., Greenwood, R.E.S., Ricketts, S.W., Rossdale, P.D., Sanderson, M. and Allen, W.R. (1982): Use of ultrasound echography for early diagnosis of single and twin pregnancy in the mare. J. Reprod. Fert, Suppl. 32, 431-439.

Squires, E.L., Tarr, S.F., Shideler, R.K. and Cook, N.L. (1994): Use of transvaginal ultrasound-guided puncture for elimination of equine pregnancies during days 50 to 65. J. Eq. Vet. Sci. 14, 203-206.

\section{Acknowledgements}

Two of the aspirations were performed at the University of Guelph, Canada in association with Drs Walter Johnson and Claire Plante and one was performed in association with Mr Andrew McGladdery of Rossdale and Partners, Veterinary Surgeons in Newmarket.

\section{Lee H.A. Morris}

University of Cambridge

Department of Clinical Veterinary Medicine

Equine Fertility Unit

Mertoun Paddocks

Wooditton Rd

Newmarket

Suffolk, CB8 9BH

U.K.

tel.: $0044-1638-662491$

fax: $0044-1638-667207$

\section{Greenwood Ellis and partners}

Reynolds House

High Street, Newmarket

Suffolk CB8 9AH

UK 